\title{
Full texts in the Czech geographical bibliography database
}

\author{
Eva Novotná \\ Director of Map Collection \\ Head of Geographical Library \\ Charles University in Prague \\ Faculty of Science \\ Albertov 6, 12843 Praha 2
}

\begin{abstract}
Open access to the documents is one of the basic requirements of databases users. Czech Geographical Bibliography On-line provides access to 185,000 bibliographical records of Bohemical geographic and cartographic documents and to more than 30,000 full texts and objects. The access is provided through a connection from the permanent storage, the Digital University Repository or a URL address of the bibliographical record. The works in public domain can directly become accessible or it is necessary to conclude licence agreement with authors, their heirs or with the editors of periodicals. Full texts of 14 titles of professional periodicals, university thesis, employees' monographs or anthologies and on-line publications are available. Digitised maps have been connected to the database since 2012. 5,500 of them are accessible from the database since the beginning of 2014. The database is an important source both for professionals and general public interested in geography and cartography.
\end{abstract}

Keywords: open access, GEOBIBLINE, geographical databases, cartographic documents

\section{Introduction}

Providing access to full texts and objects is nowadays one of the regular requirements of the information service users. The requirement of open access to information, so called open access (hereafter OA) was internationally declared several times in Budapest (2002), in Bethesda (2003) and finally in Berlin (2003) (BARTOŠEK, M., 2009). Charles University signed on to the Berlin declaration in 2013 (UK, 2013). Bibliographic database Czech Geographical Bibliography On-line ${ }^{1}$ (hereafter GEOBIBLINE) that has been produced since 2008 primarily by the Geographical library of the Faculty of Science of Charles University in Prague (NOVOTNÁ, 2011) in cooperation with other libraries headed by the National Library of the Czech Republic allows to generate metadata and subsequently to make accessible full texts of geographic and cartographic expert articles, monographs, chapters of books and anthologies, but also maps and graphics (NOVOTNÁ, 2013).

The accessibility depends on many factors: copyright laws, financing the production of bibliography of articles, creating metadata, preparation and editing of full texts and pictures,

\footnotetext{
${ }^{1}$ http://www.geobibline.cz
} 
sufficient space for data storage in the repository, provision of lifespan and migration of data, but also on technologies of access.

The first concern is the copyright law (NOVOTNÁ, VONDRÁKOVÁ, 2012). On the one hand the documents of which the propriety copyright laws are already in public domain can be accessible; on the other hand it is possible to conclude exclusive or non-exclusive license contracts with authors, their heirs or with administrators of copyright. The Geographical library of the Faculty of Science of Charles University has been using both ways. The bibliography of articles was funded from the project of the Czech Ministry of Culture in 2008-2011. Original articles were created in the Geographical library. Thanks to the Czech Ministry of Culture TEMAP ${ }^{2}$ project (technologies for making the map collections accessible) there are professionally catalogued and made accessible primarily digitised cartographic documents but also graphics and full texts of the articles. Metadata are usually generated from bibliographic records saved in the format MARC $21^{3}$. Full texts and pictures are saved in the Digital University Repository but also in the local storage at the Faculty of Science of Charles University. The access to data is carried out through a database where the full texts and pictures are attached as external links.

\section{GEOBIBLINE database}

The GEOBIBLINE database describes 185,000 Bohemical documents and provides access to a total of over 30,000 full texts and objects with metadata (to 1st April, 2014). It belongs among the world's largest non-commercial databases in the field of geography. (NOVOTNÁ, 2012) It was primarily formed for the bibliography of a wide scale of documents from the field of geography and cartography of the 20th and 21st century. It was later extended chronologically to 1450 . In content it was extended by full texts and objects. To ensure OA the database is using both green and gold way as well as other options. The green way means free access allowed by the author, the gold way is opened by the publisher and usually it is paid by the author. After the five-year experience from the Czech environment it can be observed that making something accessible in OA is not always so easily definable. There is a whole range of differences both in the editorial policy and in the approach of the authors and their heirs. In principle, a very individual approach is always required. The connection is carried out through the permanent storage of the Faculty of Science of Charles University, if the license for the work was obtained or if it is a work in public domain. The second, but unreliable option is to link URL addresses into the bibliographical record. Both types of connected full texts will display to the user as a result of the search in the left part of the screen as external links. After clicking the link it is necessary to agree the information on copyright law, where the researcher agrees to use the work only for his own need. After that the full text or the object opens. It can again have several forms depending on the way of connecting to the system.

\subsection{Full texts in the permanent storage}

The database contains full texts of articles, monographs, chapters of books and anthologies, as well as statistics. License contracts are gradually concluded with the editors of magazines,

\footnotetext{
${ }^{2}$ http://www.temap.cz

${ }^{3}$ http://www.loc.gov/marc/bibliographic/ecbdhome.html
} 


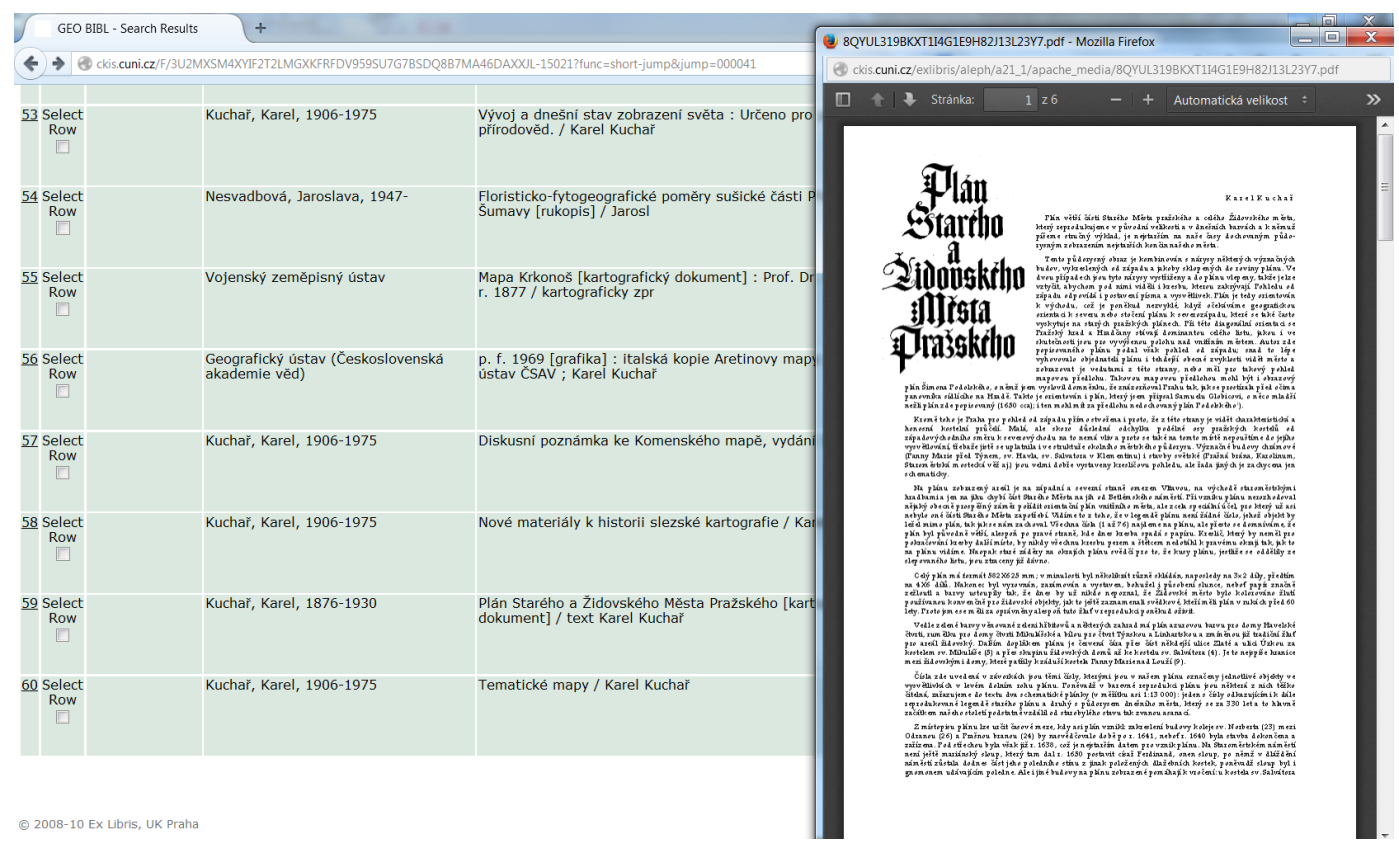

Figure 1: Example of the search interface where the external links to the full texts will display

each of which has its own publication policy. Sometimes the articles are published electronically before the printed release. It is led by an effort to speed up the process of transferring data to a potential interested person who may use and quote the article in the scientific research. Full texts of following titles are accessible: AUC Geographica, Acta Onomastica, Demografie, Folia Facultatis scientiarum naturalium Universitatis Purkynianae Brunensis. Geographia, Geodetický a kartografický obzor, Geografické rozhledy, Geografie, Kartografický přehled, Moravian geographical reports, Opera Corcontica, Scripta Facultatis scientiarum naturalium Universitatis Purkynianae Brunensis. Geographia, Sociologický časopis, Urbanismus a územní rozvoj, Vodní hospodářství, Vodohospodářské technicko-ekonomické informace and Vojenský geografický obzor. Detailed descriptions of the titles that are excerpted and supplemented by full texts can be found on the database website in the section Excerpted periodicals ${ }^{4}$. The amount of accessible volumes depends on the possibilities of the editors and of the Geographical library. In the last ten years the magazines have been editorially adapted from electronic data and the editors have usually archives available. The older articles are necessary to be scanned and read up by OCR software. The database excerpts 45 profile periodicals from the first volume. It then provides an access to 14 titles with full texts.

The accesses to monographs, chapters, anthologies are provided either directly by regular authors, i.e. employees of the Charles University or they are documents published on the Internet. The Czech Statistical Office data sets, that are commonly available electronically, are connected as well.

University theses are also a part of the database. Full texts have been accessible since 2010 . License contracts on school works are concluded with students. GEOBIBLINE provides access to works from Masaryk University and Charles University.

\footnotetext{
${ }^{4}$ http://www.geobibline.cz/cs/node/29
} 
License contracts are concluded with important authors or their heirs. The first contract was concluded with Prof. K. Kuchař, who provided license rights to the work of his father K. Kuchař. Professor Karel Kuchař (1906-1975) was an important representative of geography and cartography. Articles, monographs, reviews, New Year cards and reports have been digitized, described and added to the database. Some of the digitized documents were obtained through the contract from the Moravian library ${ }^{5}$ project National Digital Library. A web portal devoted to Prof. Kuchař ${ }^{\prime}{ }^{6}{ }^{6}$ work was created. 276 documents have been made accessible in the pdf format (CHRÁST, 2014).

A license contract with Eng. Dvořáček, the heir of Anna Dvořáčková who is a co-author of Kuchař 's book on the Moll map collection ${ }^{7}$ in Brno was concluded in 2013.

\subsection{Full texts from the linked URL addresses}

Linking full texts published on the Internet represents the second way of access. This method is not ideal, particularly because of the lack of stability of addresses and different forms of publication that are problematic. The point is that the editors often publish whole volumes or issues, which slows down the search and it is not possible to connect them directly to a specific bibliographic record of the article. In spite of a regular control of internet addresses functionality the method is not reliable. However, there is no other option until the license contract is concluded.

\subsection{Cartographic documents in the database}

The database Czech Geographical Bibliography On-line makes also accessible cartographic documents, old maps, atlases and globes (until 1850). Altogether it contains 31,000 bibliographic records of such special documents. 23 of them originated in the 16th century, 123 in the 17th century, 776 in the 18th century, from the 19th century then entire 4546 records, from the 20th century 18432 and finally from the 21st century 7874 records.

The Charles University Computer Centre has prepared a script that lists newly imported objects to a file. The script lists PID, scans the barcode field identifier in the technical metadata. Afterwards it sends a query to Aleph and adds to the PID record system a number and a title of the map sheet (according to MARC 21 field) for better traceability. Thus a generated list is sent to the Map Collection of the Faculty of Science. Bibliographic records are then connected to the objects of maps and atlases through Z39.50 protocol based on the title from the generated list. (NOVOTNÁ, 2013). Searches for Bohemical documents are made for the GEOBIBLINE database and then they are connected to the database. It is possible to view maps, zoom in and out by clicking on an external link from the database catalogue. The maps are available in the University Repository ${ }^{8}$ or directly from the GEOBIBLINE database in the jpeg2000 format at a resolution of 300 DPI under the icon FULLTEXT. The descriptive metadata can be searched in two interfaces (simple and advanced), according to fields: title, author (inverted), secondary authors, subject heading, publisher, year of publication, genre/form and language. The records may be also only browsed through and

\footnotetext{
${ }^{5}$ https://www.mzk.cz/o-knihovne/odborne-cinnosti/ndk

${ }^{6}$ http://web.natur.cuni.cz/gis/kuchar/

7 http://mapy.mzk.cz/en/

${ }^{8}$ http://repositar.cuni.cz
} 


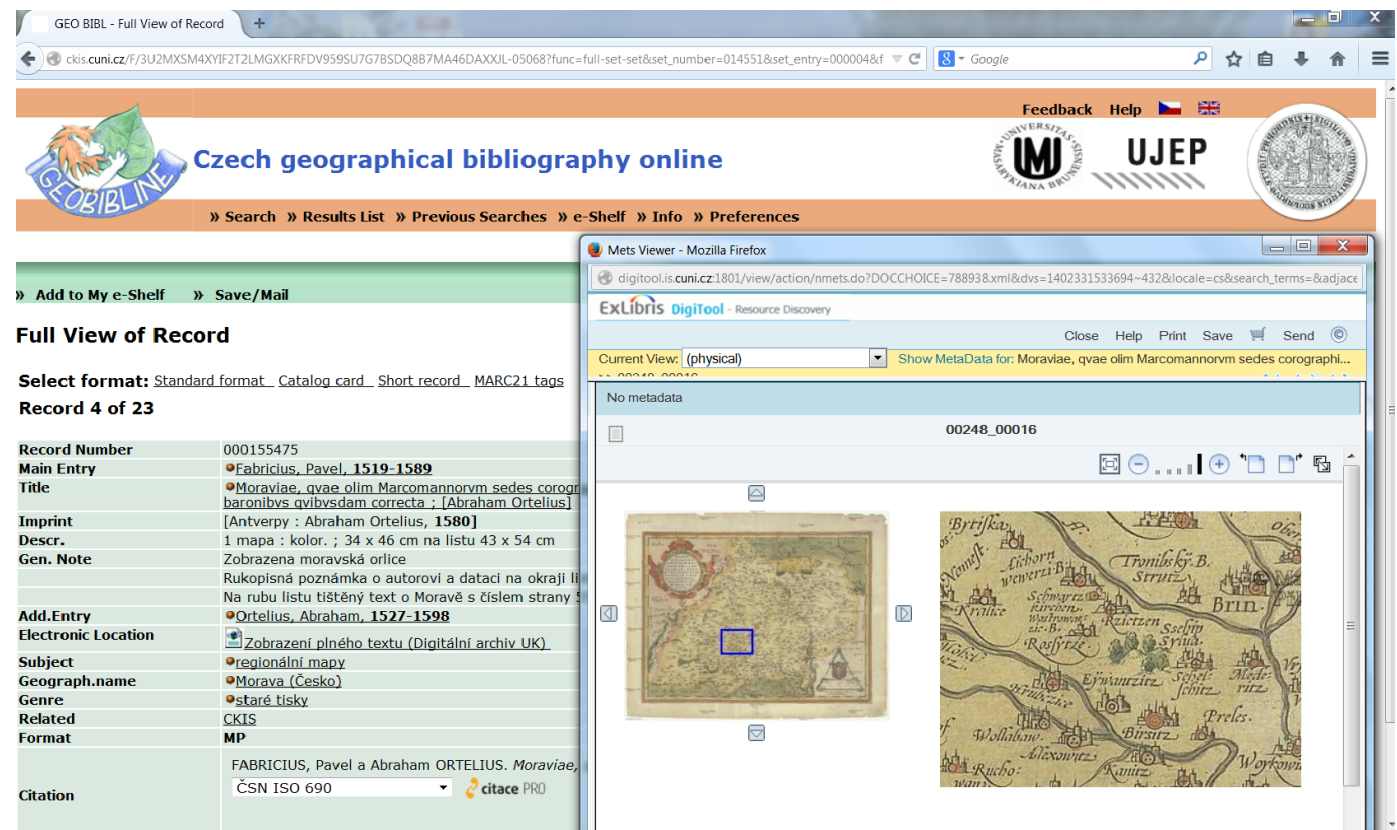

Figure 2: Sample of a map display from the GEOBIBLINE database

metadata can be viewed in three formats. The Help icon (a question mark) is up on the right. The access is possible both in Czech and English (globe icon). Metadata are in MIX format.

The GEOBIBLINE database provides an on-line access to 20 maps from the 16th century, 96 maps from the 17th century, 689 maps from the 18th century and 4695 from the 19th and 20th centuries.

\section{Conclusion}

The database development continues thanks to the TEMAP project. A shared collection of bibliographic records from participating libraries and original cataloguing of the works in the Geographical library and in the Map Collection of the Faculty of Science are going on. Digitized maps are also gradually being uploaded to the database and connected to the records. The digital repository contains 32,000 digitized cartographic documents. By the end of the project in 2015 their number should increase of 20,000. Not all of them are, however, cartographic bohemics. Even so, their share will be fairly high. Photographs of globes and telluriums are beginning to be connected as well. The database websites collect also statistical information on accesses from abroad. Apart from the Czech users the websites are frequently visited from the United States of America, Germany, the Netherlands, Russia, Ukraine and Spain. On the contrary, the number of visitors from Slovakia is surprisingly low.

\section{Acknowledgement}

This article was supported through the project of the Czech Ministry of Culture, DF11P01OVV003, TEMAP - Technology for discovering of map collections of the Czech Republic: methodology and software for protection and use of cartographic works of the national cartographic heritage. 


\section{References}

[1] BARTOŠEK, M. 2009. Open access - otevřený přístup $k$ vědeckým informacím. Úvod do problematiky. Zpravodaj ÚVT MU. ISSN 1212-0901, 2009, roč. XX, č. 2, s. 1-\%.

[2] CHRÁST, J. 2014. Nový web věnovaný prof. Karlu Kuchařovi. Ikaros [online]. 2014, roč. 18, č. 2 [cit. 04.04.2014]. Available: http://www.ikaros.cz/node/8155

[3] NOVOTNÁ, Eva a kolektiv. 2011. Geografická bibliografie ČR online: GEOBIBLINE. Praha: VŠCHT. 152 s. : il. ISBN 978-80-7080-773-6. Available: http://vydavatelstvi. vscht.cz/katalog/uid_isbn-978-80-7080-773-6/anotace/.

[4] NOVOTNÁ, Eva a Alena VONDRÁKOVÁ. 2012. Zpřístupnění a užití digitalizovaných kartografických děl. Geografické rozhledy. 2012, roč. 22, č. 3, příloha, s. 1-4. ISSN 12103004 .

[5] NOVOTNÁ, Eva. 2012. Base de datos GEOBIBLINE y su comparación con las bases geográficas existentes en el mundo. El profesional de la información. Roč. 21, č. 3, s. 304-311. ISSN 1386-6710.

[6] NOVOTNÁ, Eva. 2013. Staré mapy a grafiky v Geografické bibliografii ČR on-line. Knihovna - knihovnická revue [online]. Roč. 24, č. 1, s. 5-27. ISSN 1801-3252. Available: http://knihovna.nkp.cz/knihovna131/13105.htm

[7] Univerzita Karlova. 2013. UK se přihlásila k Berlínské deklaraci Open Access. Iforum [online]. 2013, [cit. 04.04.2014]. Available: http://iforum.cuni.cz/IFORUM-14799.htm] 